\title{
STRATEGI KOMUNITAS PEKA KOTA HYSTERIA DALAM PELESTARIAN KAMPUNG KOTA (STUDI KASUS: KAMPUNG BUSTAMAN KOTA SEMARANG)
}

\author{
Rojab Umar Abdilla ${ }^{1}$ \\ Linda Darmajanti ${ }^{2}$ \\ Kajian Pengembangan Perkotaan, Sekolah Kajian Stratejik dan Global Universitas Indonesia ${ }^{1,2}$ \\ Penulis Korespondensi e-mail: erojab@gmail.com
}

\begin{abstract}
Kampung is an embryo of a city. Metropolitan city is growing from a kampung. The city growth has good and bad impacts. Semarang City has 6.6 million population and in the process of its development, four old kampungs have been evicted by the developer during 2005 to 2018, either for hotel or apartment. A kampung whose population is middle to lower economy is an easy target for developer. This condition has triggered Peka Kota Hysteria community which focuses on the issue of arts and urban youth to preserve kampungs in the urban area i.e kampung Bustaman. This study revealed KPK Hysteria's internal and external factors in preserving kampung Bustaman and will reveal strategies used by KPK Hysteria. Through the strategy implemented namely 1. Based on local culture, 2. Optimizing the involvement of the resident of kampung Bustaman and 3. Using art movement through internal network. These three strategies are implemented by KPK Hysteria with systematic steps. KPK Hysteria is considered capable and succeeded in preserving kampung Bustaman with the supporting for 6 years. This success can bee seen from the increasing social captal of kampung Bustaman: changes in social norm, the existence of social control, network, trust, and the most impact for the resident is the improvement of Human Resources, especially for the youth in kampung Bustaman .
\end{abstract}

Key Words: Strategy, Community, Urban Kampung.

\begin{abstract}
ABSTRAK
Kampung merupakan embrio dari sebuah kota. Berawal dari sebuah kampung lalu tumbuh menjadi kota metropolitan. Pertumbuhan kota memang berdampak baik namun juga ada dampak buruknya. Kota Semarang dengan populasi 6,6 juta jiwa dalam proses pembangunannya didapati ada empat kampung lama yang digusur oleh developer dalam kurun tahun 2005 hingga 2018, baik itu dibangun hotel maupun apartemen. Keberadaan kampung yang penduduknya berekonomi menengah ke bawah merupakan sasaran empuk bagi developer. Kondisi ini memicu komunitas Peka Kota Hysteria yang fokus pada isu anak muda seni dan perkotan untuk bergerak melestarikan kampung-kampung di perkotaaan salah satunya kampung Bustaman. Penelitian ini mengungkap faktor internal dan eksternal KPK Hysteria dalam melestarikan kampung Bustaman. Serta akan mengungkap strategi yang digunakan oleh KPK Hysteria. Melalui Strategi yang diterapkan yaitu 1. berbasis budaya lokal, 2. pengoptimalan keterlibatan warga kampung Bustaman, dan 3. menggunakan gerakan seni melalui jaringan internal. Tiga hal tadi diterapkan oleh KPK hysteria dengan langkah-langkah yang sistematis. KPK hysteria dinilai mampu dan berhasil melestarikan kampung Bustaman dengan pendampingan selama 6 (enam) tahun. Keberhasilan ini dapat dilihat dari peningkatan modal sosial yaitu : perubahan norma sosial, adanya kontrol sosial,jaringan, trust, dan yang paling dirasakan yaitu peningkatan Sumber Daya Manusia khususnya remaja pada kampung Bustaman.

Kata Kunci : Strategi, Komunitas, Kampung kota.
\end{abstract}




\section{PENDAHULUAN}

Kampung kota adalah suatu bentuk pemukiman di wilayah perkotaan yang khas Indonesia dengan ciri antara lain: penduduk masih membawa sifat dan prilaku kehidupan pedesaan yang terjalin dalam ikatan kekeluargaan yang erat, kondisi fisik bangunan dan lingkungan kurang baik dan tidak beraturan, kerapatan bangunan dan penduduk tinggi, sarana pelayanan dasar serba kurang, seperti air bersih, saluran air limbah dan air hujan, pembuangan sampah dan lainnya. (Budiharjo, 1992 ). Kota Semarang mulai terbentuk dari kampungkampung kota yang tercipta dari pendatang yang singgah untuk berdagang maupun bertempat tinggal. Terbentuknya suatu kota dimulai dari pinggir sungai, karena aktivitasnya yang sangat membutuhkan sumber air sebagai keperluan sehari-hari maupun untuk sarana transportasi air, memudahkan dalam melakukan aktivitas perdagangan. Begitu pula dengan Kota Semarang, bantaran sungai di Semarang merupakan dasar pembentukan embrio Kota Semarang awal mulanya. Menurut peta Semarang tahun 1965, embrio Kota Semarang berada di kawasan yang menjadi kawasan pasar Johar bantaran sungai Banjir kanal (Wijanarko, 2001).

Menurut Setiawan (2010), secara fisik, sebagian kampung dicirikan dengan ketidakaturan, ketidakseragaman, ketidakmapanan, dan bahkan mungkin ketidakamanan serta ketidaksehatan. Semakin banyaknya pendatang dari luar kota dengan kekuatan ekonomi yang lemah menambah tingkat kepadatan kampung kota. Ditambah keterikatan warga pendatang dengan kampung masih rendah sehingga kepedulian terhadap kampung tersebut rendah. Lanjut menurut Setiawan (2010) dapat dikatakan bahwa sebagian besar warga miskin kota tinggal dan hidup di kampung. Pendatang baru dari pedesaan menjadikan kampung sebagai batu pijakan untuk mengarungi masa depan mereka di lingkungan kota.

Saat ini kota Semarang berkembang semakin modern dan tentunya semakin menarik banyak peminat untuk datang ke kota ini. Hal tersebut dikarenakan berbagai faktor. Selain perannya sebagai ibu kota dan pusat pemerintahan Jawa Tengah, Semarang juga didukung dengan wilayah strategis sebagai kota pelabuhan yang mengalirkan arus perdagangan. Lahan yang terbatas di pusat kota merupakan aset berharga sehingga atas nama optimalisasi, pengalihfungsian lahan marak dilakukan baik dari pemerintah maupun developer. Sebagai contoh di dalam penelitian (Evansyah, 2013) Kampung Sekayu di Kota Semarang yang terancam keberadaan di tengah perkembangan kota yang terjadi salah satunya yaitu dengan adanya Mal Paragon yang berdiri pada tahun 2010, karena Kampung Tua Sekayu daerah yang 
paling dekat. Mal Paragon telah menghilangkan RT 1 yang sekarang ini telah dijadikan lokasi lahan parkir mal, selain itu Mal Paragon ingin memperluas kawasan bisnis dan telah melakukan pendekatan kepada masyarakat Kampung Sekayu. Dan juga mirip kasus seperti Sekayu lebih dulu, yaitu penggusuran kampung Jayenggaten pada tahun 2005 lalu (Detik.com/2005).

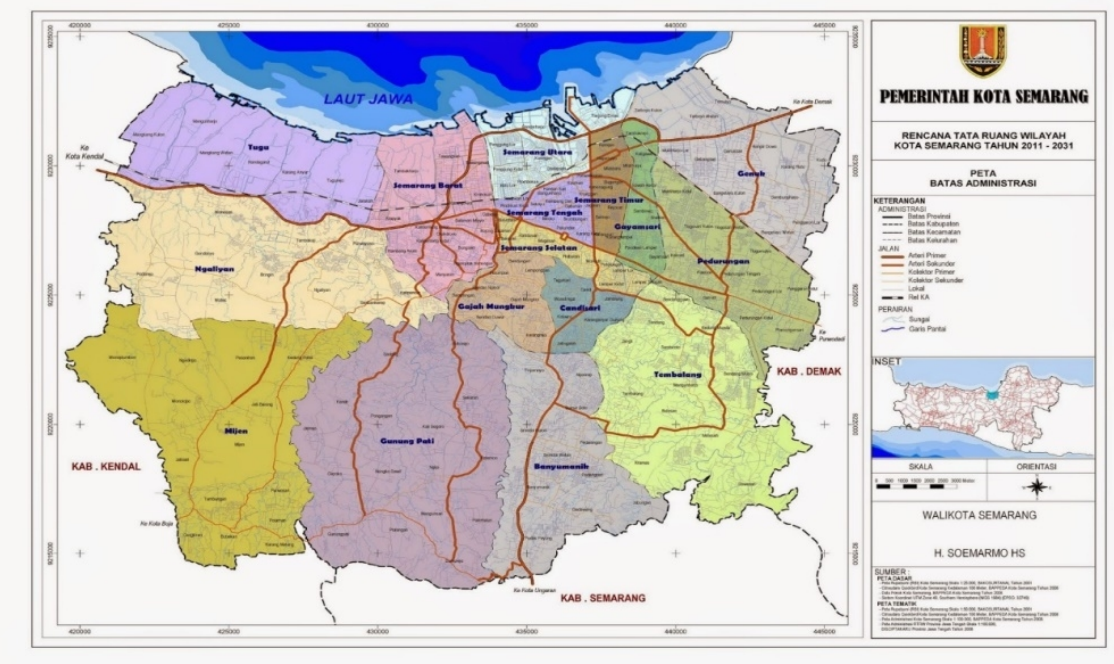

Gambar 1. Administrasi Kota Semarang Sumber : Distarung Kota Semarang, 2018

Semarang merupakan Ibukota Jawa tengah dengan jumlah penduduk per 2017 yaitu sebanyak 1.602.717 jiwa dengan luas administrasi 373, $8 \mathrm{Km}^{2}$, memiliki 16 kecamatan, 177 kelurahan. Kota yang sejak awal dibangun untuk perdagangan dan bisnis kini sudah menjadi kota metropolitan. Segala aktivitas ekonomi tumbuh subur di Kota Semarang. Kenaikan kepadatan penduduk terus melaju dari tahun 2011 hingga sekarang terbukti dari data BPS menunjukkan di tahun 2011 Kota Semarang memiliki jumlah penduduk sebanyak 1.544.358 jiwa dibandingkan dengan tahun 2017 berjumlah 1.602 .717 jiwa.

Terbatasnya lahan di Kota Semarang dapat menjadi sumber masalah bagi penduduk kota. Oleh sebab itu pemerintah sebaiknya merencanakan tata guna lahan secara komprehensif serta hati-hati dan tidak mengakomodir kepentingan beberapa pihak saja. Dengan infrastruktur yang lengkap serta menjadi kekuatan ekonomi di Jawa Tengah, Kota Semarang menjadi tujuan bagi pendatang dari kota-kota sekitar. Hal ini sedikit banyak mempengaruhi pertambahan penduduk di Kota Semarang. Dengan tingkat konsumsi tertinggi di Jawa Tengah 
maka Kota Semarang juga menjadi target pasar bagi para pengembang properti. Di sini posisi kampung kota sangatlah riskan karena dihuni oleh warga-warga yang berekonomi lemah serta status tanah yang kadang masih belum jelas karena turun-temurun dari hasil warisan atau sejak lama memang bermukim di sana tanpa ada pikiran untuk mengurus surat tanah. Kampungkampung lama di Kota Semarang terletak di beberapa tempat yaitu dominan di Semarang Tengah serta Semarang Utara.

Berikut beberapa data kampung yang tengah terkena penggusuran oleh pihak hotel maupun developer.

Tabel 1. Daftar Kampung yang Tergusur di Kota Semarang

\begin{tabular}{|l|l|l|l|l|}
\hline No & \multicolumn{1}{|c|}{ Nama Kampung } & \multicolumn{1}{|c|}{ Kecamatan } & \multicolumn{1}{|c|}{ Eksekusi } & \multicolumn{1}{|c|}{ Eksekutor } \\
\hline $\mathbf{1}$ & Kampung Jayeggaten & Semarang Tengah & 2005 & Hotel Gumaya \\
\hline $\mathbf{2}$ & Kampung Sekayu & Semarang Tengah & 2008 & Mal Paragon \\
\hline $\mathbf{3}$ & Kampung Kebonharjo & Semarang Utara & 2016 & PT KAI \\
\hline $\mathbf{4}$ & Kampung Kebonsari & Semarang Tengah & 2016 & Hotel Plampitan \\
\hline
\end{tabular}

Dilihat dari penggusuran kampung lama di Kota Semarang didominasi daerah kecamatan Semarang Tengah. Memang lokasi di Semarang Tengah sangatlah strategis, berada pada pusat kota dan termasuk dalam Center Bussines District (CBD) Kota Semarang. Penggusuran akan mudah saja dilakukan kepada kampung-kampung yang warganya tidak mempunyai geliat aktivitas yang kuat dalam menunjukkan keterikatan warga dengan kampungnya. Kampung yang berpotensi digusur ialah kampung yang warganya sudah tidak guyub, sudah individualis, sehingga jika ada budaya khas daerah lokal warganya sudah enggan untuk melestarikan, bahkan ada beberapa rumah yang disewakan menjadi kos-kosan oleh warga, sehingga keterikatan manusia dengan kampungnya menjadi rendah.

Munculnya kelompok komunitas lokal yaitu Komunitas Peka Kota Hysteria (KPK Hysteria) di kota Semarang menjadi isu yang kontradiktif dengan ciri masyarakat perkotaan sekarang ini sebagaimana yang disebutkan oleh Suparlan (2004) bahwa masyarakat perkotaan memiliki sifat individualisme, egosentrik, menomorsatukan uang dan persaingan antar individu dan kelompok. Selain itu, Djohan (2007) berpendapat bahwa pengaruh globalisasi dan lahirnya industri-industri besar di Indonesia menyebabkan masyarakat kita berubah dari masyarakat desa menjadi masyarakat kota. Kampung Bustaman merupakan sebuah 
perkampungan yang berada di tengah kota Semarang. Seperti kampung yang lainya Bustaman sebagian besar dihuni masyarakat miskin, rentan dengan penggususran, penuh keterbatasan. KPK Hysteria pada 2013 mampu meningkatkan modal sosial kampung Bustaman dalam berjejaring dan berkegiatan. Atas dasar itulah penelitian ini kami lakukan untuk mendalami strategi apa yang dilakukan serta faktor apa saja yang mendukung terciptanya upaya pelestarian kampung Bustaman.

\section{METODOLOGI PENELITIAN}

\subsection{Kajian Pustaka}

Koentjaraningrat (1990) dalam Soekanto (2009) menyatakan bahwa suatu kelompok adalah suatu masyarakat kecil yang saling berinteraksi antar anggotanya yang diatur oleh adat istiadat dan sistem-sistem norma tertentu secara kontinyu serta adanya rasa identitas yang mempersatukan semua anggotanya. Sosiologi dan psikologi modern memusatkan pada tingkah laku manusia yang hidup bersama kelompok, kelompok dibentuk atas suatu kepentingan yang jelas sesuai dengan kebutuhan anggota.

Menurut Robbins (dalam Kusdi, 2009) "pengertian strategi dalam konteks organisasi adalah penetapan berbagai tujuan dan sasaran jangka panjang yang bersifat mendasar bagi sebuah organisasi, yang dilanjutkan dengan penetapan rencana aktivitas dan pengalokasian sumber daya yang diperlukan guna mencapai berbagai sasaran tersebut." Terdapat dua pendapat yang menonjol mengenai bagaimana strategi disusun dalam organisasi. Kelompok pertama adalah mereka yang menyakini bahwa strategi merupakan suatu tindakan (planning mode). Hal ini berkaitan dengan model rasional yang dikembangkan para pemikir perspektif modern. Kelompok kedua, yang disebut evolutionary mode, melihat bahwa strategi tidak mesti berupa suatu perencanaan yang sistematis dan terperinci. Mereka melihat bahwa dalam praktiknya tidak jarang pengelola organisasi mengambil keputusan strategi secara bertahap atau selangkah demi selangkah, sejalan dengan perkembangan organisasi itu sendiri, sebelum pada akhirnya menjadi suatu strategi yang utuh dan lengkap.

Modal sosial mampu digunakan untuk pembangunan berkelanjutan. (Rohe, 2004). Pembangunan komunitas berkelanjutan bergantung pada Kekuatan komunitas untuk menyelesaikan masalahnya sendiri. Kekuatan komunitas terdiri dari . 1.modal sosial, 2.modal lingkungan , 3.modal finansial serta 4. modal budaya. (Darmajanti, 2018) Tanpa adanya modal 
sosial yang kuat pembangunan berkelanjutan mustahil terjadi. modal sosial merupakan kunci utama untuk pembangunan berkelanjutan. Coleman, seorang sosiolog, mendefinisikan modal sosial didefinisikan oleh fungsinya, bukan satu entitas (sifat tertentu), meski dari berbagai macam entitas yang berbeda, namun mempunyai dua karakteristik yang sama yaitu (1) terdiri dari beberapa aspek struktur sosial, dan (2) memfasilitasi tindakan tertentu dari pelaku atau orang atau perusahaan dalam struktur tersebut. Di samping itu Coleman juga mendefinisikan modal sosial sebagai kemampuan orang untuk bekerja sama guna tujuan umum kelompok dan organisasi (Coleman 1988, dalam Bjornskov C dan Svevdsen G. T., 2000)

'Modal sosial bukanlah sesuatu yang stagnan melainkan dapat dibangun maupun dilemahkan. (Ann Dale, 2005) dalam Darmajanti (2018). menjelaskan bahwa ada beberapa tahapan untuk membangun modal sosial bisa dilihat di grafik berikut.

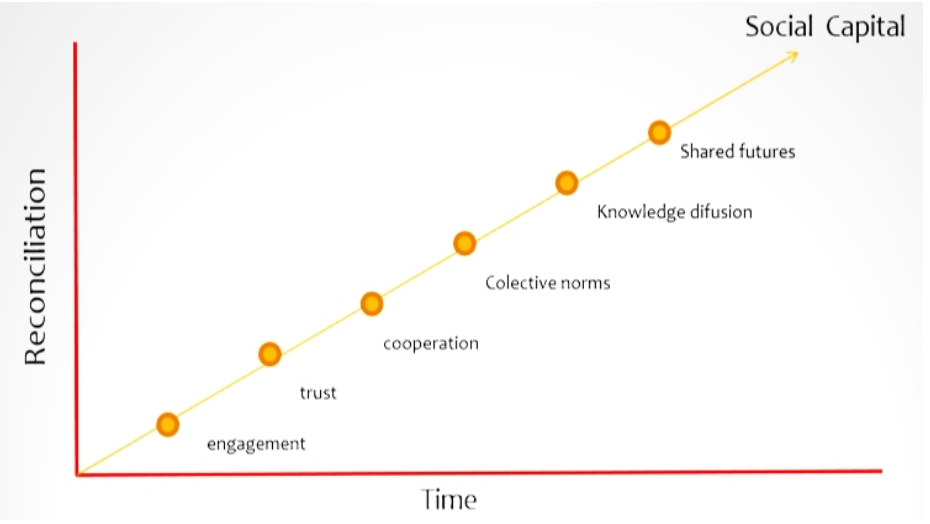

Gambar 2. Peningkatan Modal Sosial

Sumber : Dale, 2015

Sesuai grafik di atas bahwa dalam membangun modal sosial diperlukan beberapa tahapan yang ditunjukkan dalam dimensi rekonsiliasi dan waktu yaitu pertama dengan adanya perjanjian (engagement), kepercayaan (trust), kerja sama (cooperation), aturan bersama (collective norms), menyebar pengetahuan (knowledge diffusion), dan shared futures, sedangkan menurunnya modal sosial dapat digambarkan sebagai berikut: 


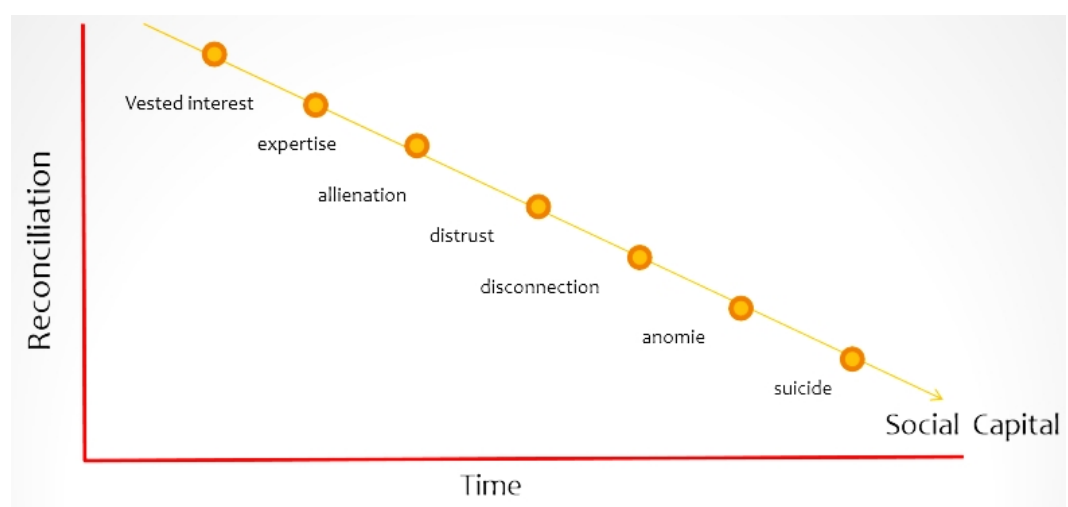

Gambar 3. Penurunan Modal Sosial Sumber : Dale, 2015

Grafik di atas menunjukkan bahwa aspek yang membuat penurunan kualitas modal sosial antara lain: kepentingan pribadi (vested interest), keahlian (expertise), mengasingkan diri (allienation), ketidakpercayaan (distrust), pemisahan (disconnection), keadaan kacau (anomie), bunuh diri (suicide).

\subsection{Metodologi}

Metode yang digunakan dalam penelitian ini adalah metode kualitatif. Melalui pendekatan kualitatif, peneliti dapat mempelajari proses dan mendapatkan perspektif dan makna dari informan kunci untuk kehidupan sehari-hari di wilayah tersebut, atau pada gejala yang mereka alami baik di tempat itu atau di tempat lain. Kualitatif penelitian adalah penelitian yang bermaksud untuk memahami fenomena apa yang dialami oleh penelitian subyek seperti perilaku, persepsi, motivasi, tindakan, dll, secara holistik, dan dengan cara deskripsi dalam bentuk kata-kata dan bahasa, dalam konteks khusus yang alami dan dengan memanfaatkan berbagai alam metode (Moleong, 2006). Penelitian ini menggunakan pendekatan studi kasus. Studi kasus berfokus pada status subjek penelitian yang berkaitan dengan fase tertentu atau khas dari seluruh kepribadian. Subjek penelitian bisa menjadi individu, kelompok, lembaga, dan masyarakat. Tujuan dari studi kasus adalah untuk memberikan rincian ikhtisar latar belakang, sifat, dan karakteristik kasus, atau status individu, yang kemudian karakteristik di atas akan dibuat umum (Nazir, 1988). Pendekatan studi kasus mencari lihat latar sejarah, pengaturan fisik dan kaitkan konteks dengan teori yang akan 
digunakan (Septiady, 2018). Pelajaran ini memiliki keterbatasan pada peran aktor, kelompok, modal sosial dan berbasis masyarakat di Komunitas Peka Kota Hysteria dan Kampung Bustaman Kota Semarang. Tahapan analisis data dalam penelitian ini meliputi temuan lapangan, matriks, kategorisasi, abstraksi yang terkait dengan teori dan hasil analisis.

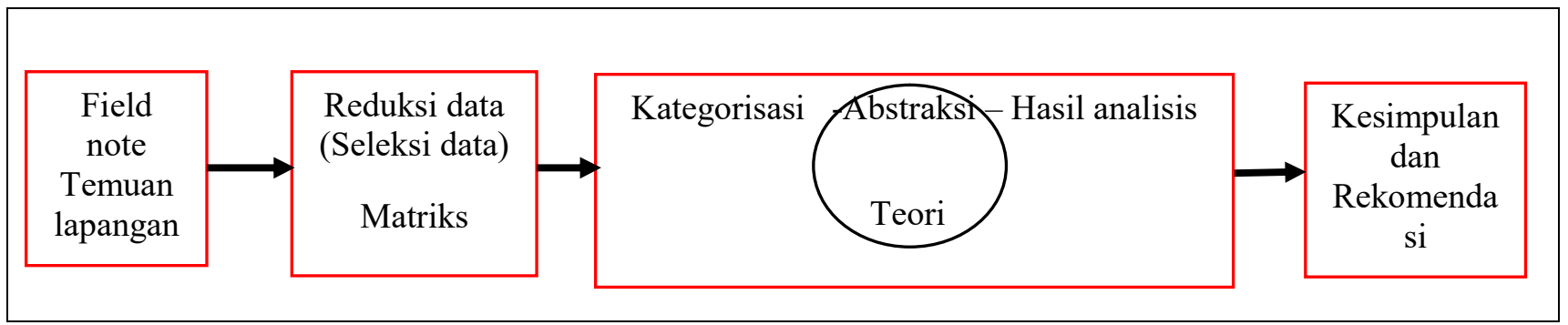

Gambar 4: Bagan Tahap Analisis data

Sumber : Hasil Analisis, 2018

Dalam menganalisis data, para peneliti juga memiliki pengukuran analisis terhadap temuan danteori yang dinyatakan dalam skala. Skala ini dalam bentuk angka scoring dari 1-10 dengan rendah, sedang dan kualitas tinggi.

Tabel 2. Penilaian Kualitatif

\begin{tabular}{|c|c|}
\hline Skala & Kualitas \\
\hline $1-3$ & Rendah \\
\hline $4-6$ & Sedang \\
\hline $7-10$ & Tinggi \\
\hline
\end{tabular}

Skala ini dibuat oleh penulis pertama dalam melakukan penilaian kualitatif. Penilaian ini dibuat untuk melakukan pengukuran pada analisis yang membahas temuan dan konsep yang dirujuk. Ini menyadari bahwa idealnya, konsep yang diperhatikan oleh peneliti bergantung pada sejauh mana interpretasi peneliti atas temuan di lapangan. 


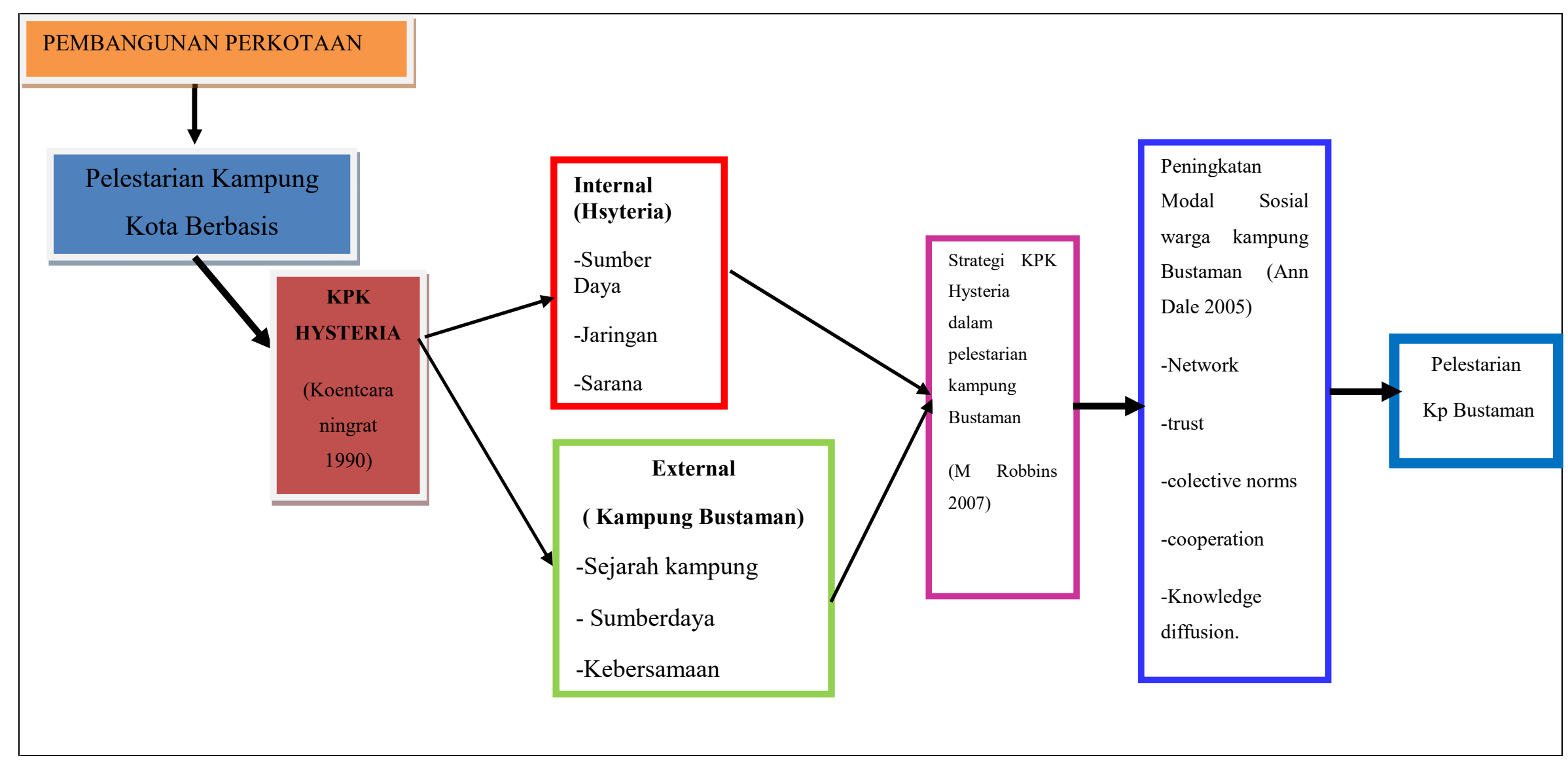

Gambar 5 :Kerangka pikir

Sumber : Hasil Analisis, 2018 


\section{HASIL DAN PEMBAHASAN}

\subsection{Gambaran Umum Kampung Bustaman dan Komunitas Hysteria}

Kampung Bustaman adalah salah satu kampung lama kota yang terletak di RW III, Kelurahan Purwodinatan, Kecamatan Semarang Tengah, Kota Semarang. Kampung Bustaman memiliki luas wilayah sekitar 0,6 Ha dan terdiri atas 2 wilayah RT, yaitu RT 04 dan RT 05 . Kampung Bustaman memiliki jumlah penduduk sebanyak 354 jiwa atau 101 KK. Kepadatan penduduk di Kampung Bustaman mencapai 590 jiwa/Ha dan tergolong sebagai pemukiman berkepadatan sangat tinggi. Kampung Bustaman masih didominasi oleh warga berusia produktif, yaitu antara 15-60 tahun sekitar 65\% dari total jumlah penduduk (Sudarwanto, 2017). Berbatasan dengan kampung Pekojan (etnis India-Pakistan) serta Kampung Pecinan membuat warga Kampung Bustaman sudah terbiasa dengan perbedaan.
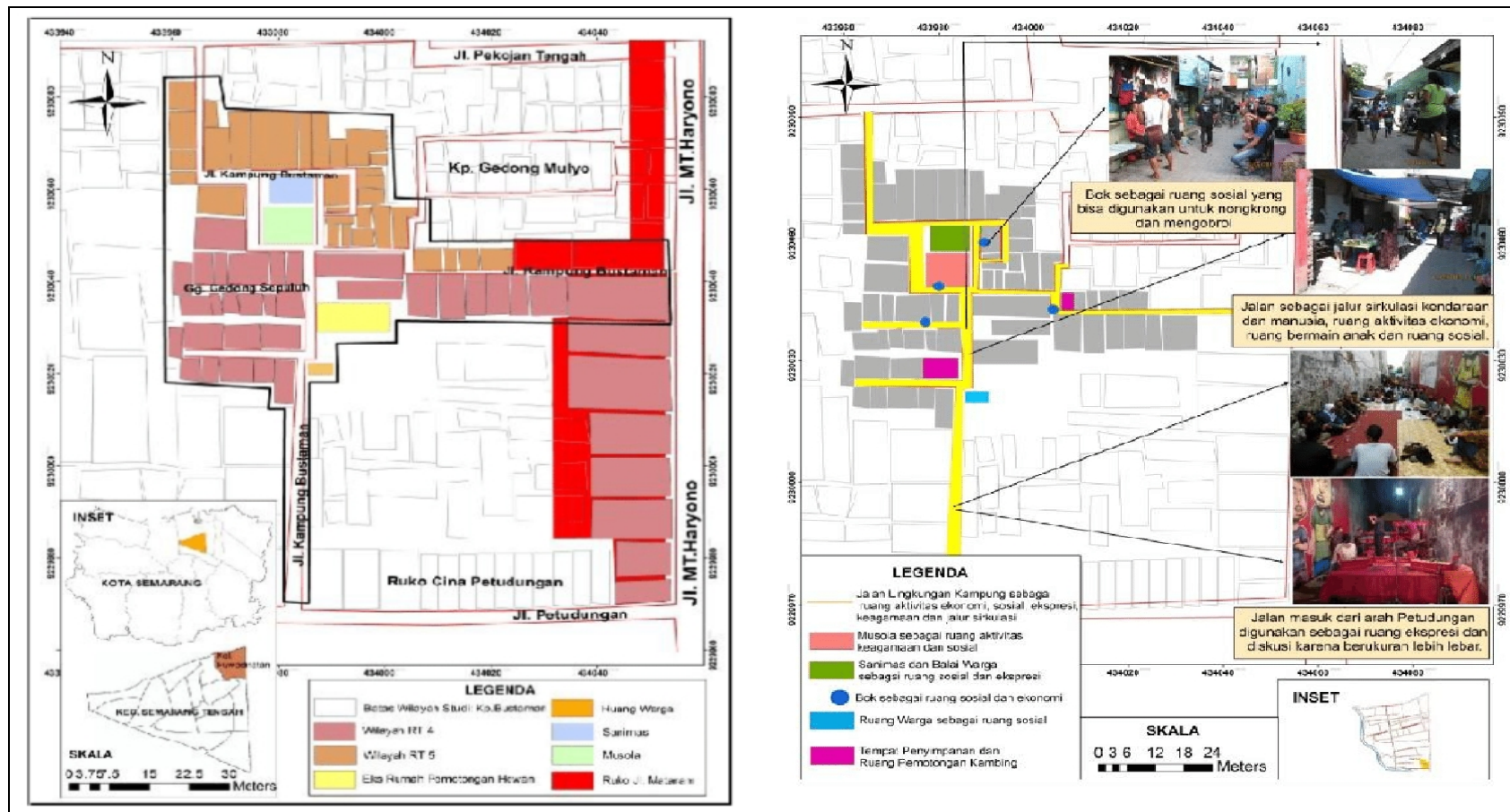

Gambar 6 Peta Kampung Bustaman dan Peta Pemanfaatan Ruang di Kampung Bustaman

Sedangkan untuk komunitas Hysteria, tanggal didirikanya komunitas Hysteria mengikuti tanggal terbit zine lembaran yang berisi sajak-sajak sastra ditanggal 11 September 2004 oleh Yuswinardi, mahasiswa Universitas Diponegoro jurusan Sastra Indonesia. Tahun 2005 Ahmad Khairudin ikut tertarik dalam kegiatan penerbitan zine tersebut. Zine atau 
selebaran itu awalnya berbayar, hanya saja biaya photocopy sengaja ditekan murah agar mudah dalam penyebarannya. Zine tersebut dinamai Hysteria "Lembar Sastra Bawah Tanah". Kang Yus dan Adin memulai gerakan kesusastraan dari lingkup kampus hingga Kota Semarang. Pada tahun 2007 Yuswinardi harus pulang ke Blora, sejak itu Adin, panggilan Ahmad Khairudin, memegang penuh penerbitan zine Hysteria tersebut. Pada 2011 Hysteria berfokus pada isu seni anak muda dan isu perkotaan dipicu kepedulian tentang kondisi perkotaan di kota Semarang. Sampai saat ini KPK Hysteria memegang 9 jaringan Kampung Kota, yangmana kmapung Bustaman adalah pilot project pertama yang menjadi prototype strategi gerakan KPK Hysteria di kampung.

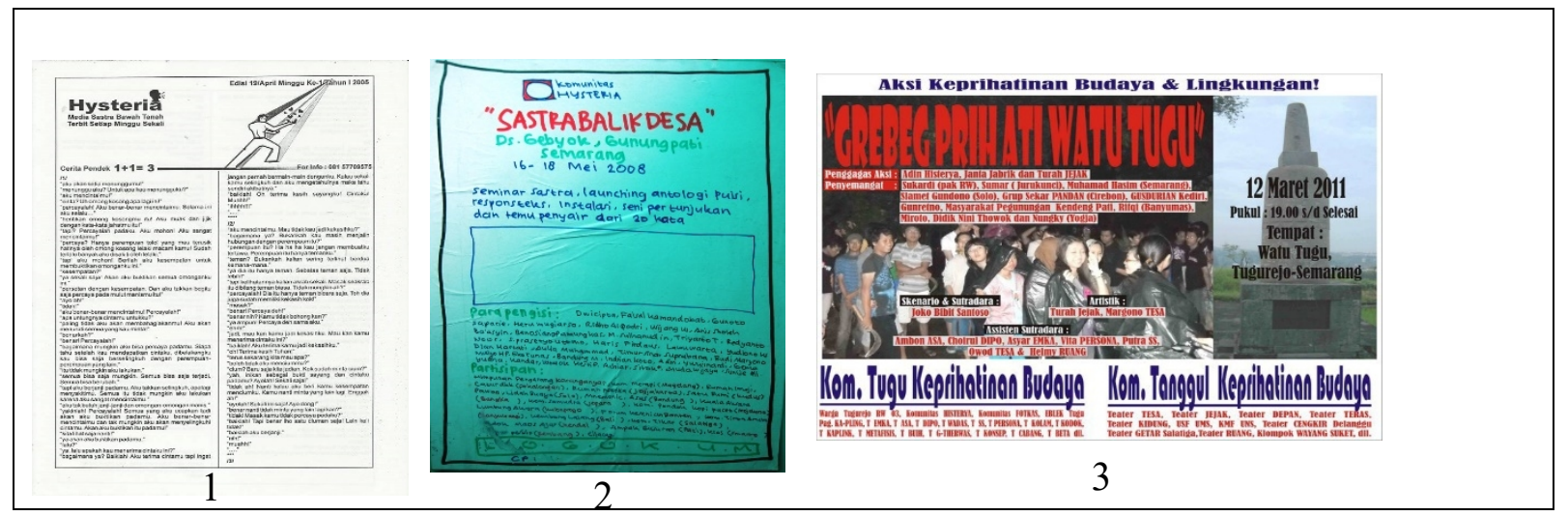

Gambar 7 : 1. Zine Hysteria (2005) 2. Desain Layout zine ' Sastra Balik Desa' (2008) 3. Poster Grebeg Prihati Tugu (2011)

Sumber : Dokumen Hysteria, 2012

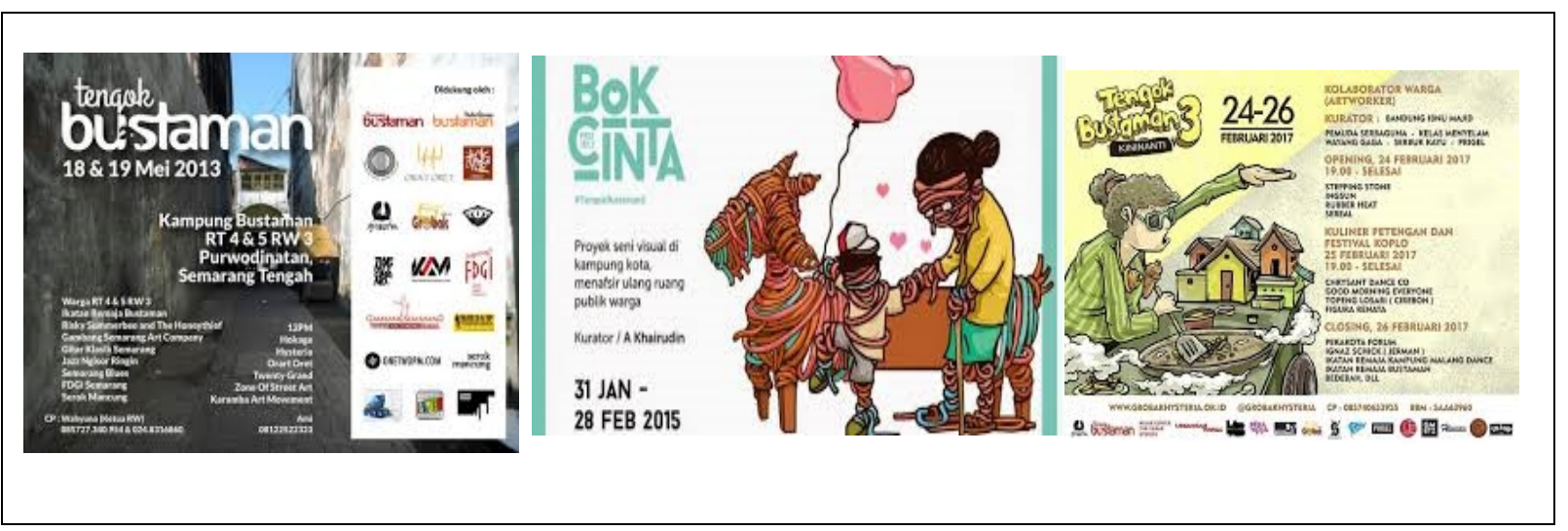

Gambar 8. Poster Tengok Bustaman acara Hysteria dua tahunan dimulai dari 2013 hingga ketiga kalinya terakhir di tahun 2017

Sumber : Khoirudin, 2015 dan Dokumen Hysteria, 2018 


\subsection{Pembahasan Strategi Komunitas}

Berikut akan kami paparkan mengenai poin pokok dalam strategi pelestariaan kampung Bustaman oleh KPK Hysteria .

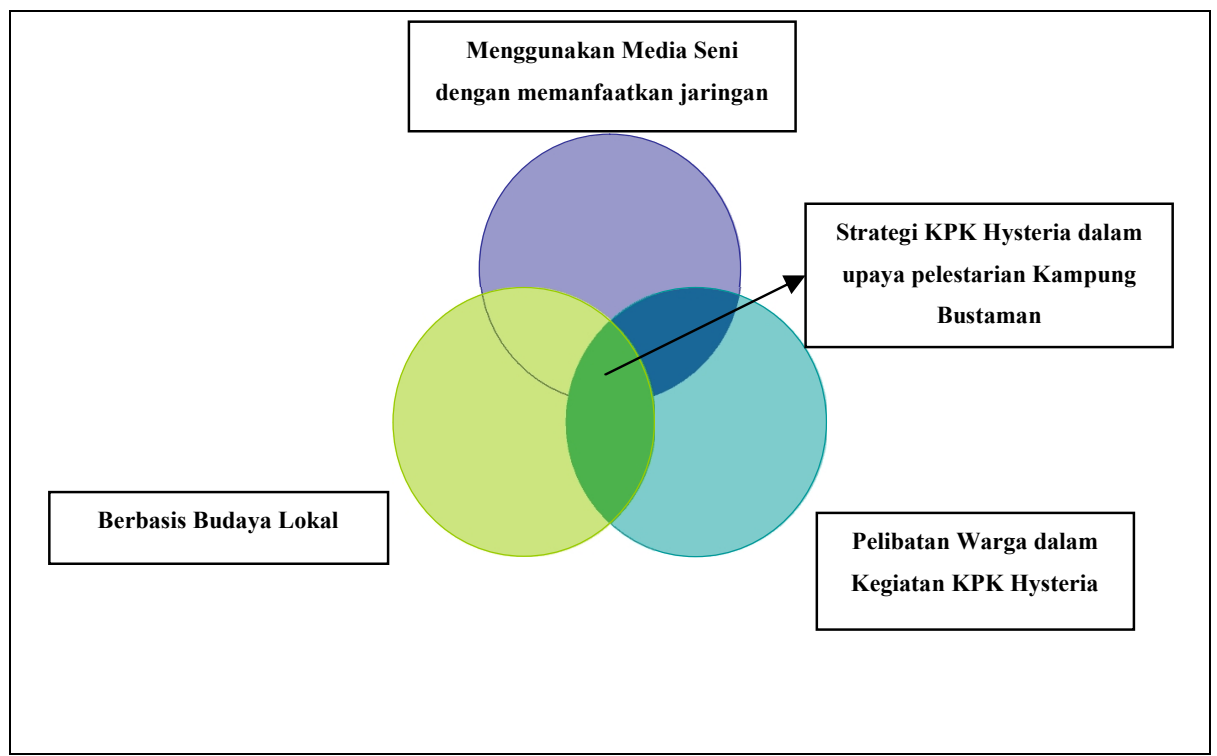

Gambar 9. Strategi KPK Hysteria dalam upaya pelestarian Kampung Bustaman Sumber : Hasil Analisis, 2018

Dari gambar diatas maka dapat diketahui bahwa aspek strategi KPK Hysteria terbagi dalam tiga pendekatan yaitu budaya, media seni dan warga.

\subsubsection{Berbasis Budaya Lokal}

Mengenai gerakan dengan basis budaya lokal, KPK Hysteria dalam upayanya mengangkat sejarah, peristiwa atau bahkan cerita kegiatan sehari-hari warga Kampung Bustaman. Dalam Tengok Bustaman 1 tahun 2013, KPK Hysteria mengangkat Sejarah Kyai Bustam, Kegiatan usaha warga yaitu jagal kambing, menarasikan MCK Komunal yang ada di Kampung Bustaman. Pada Tengok Bustaman 2 tahun 2015, KPK Hysteria mengangkat isu spasial dengan judul "Bok Cinta" yang mana terminologi tersebut sebetulnya sudah ada sebelumnya namun diangkat oleh KPK Hysteria untuk dijadikan nama sebuah festival. Kemudian ada fenomena "Gedong sepuluh" yang turut dijadikan objek festival. Lalu terakhir pada Tengok Bustaman 3 tahun 2017 KPK Hysteria mengangkat kuliner khas Kampung Bustaman dengan festival gule Bustaman hingga merespon gerobak-gerobak warga yang menjadi pedagang gule Bustaman. 


\subsubsection{Menggunakan media seni dengan memanfaatkan jaringan}

Seni dianggap sebagai media yang paling soft serta mudah diterima oleh masyarakat. Selain itu memang embrio KPK Hysteria sendiri berangkat dari gerakan seni. Oleh sebab itu media seni dijadikan salah satu ujung tombak dalam setiap gerakan KPK Hysteria. Konsep kolaboratif hub diyakini oleh KPK Hysteria sebagai cara yang paling efektif untuk mencapai tujuan komunitas. Didasari keterbatasan-keterbatasan yang dimiliki oleh SDM KPK Hysteria, mereka menggunakan jaringan para seniman untuk saling melengkapi keterbutuhan dalam upaya pelestarian Kampung Bustaman. Jaringan ini menjadi salah satu kekuatan internal KPK Hysteria. Jaringan KPK Hysteria berasal dari kegiatan serta dunia seni yang digeluti masing masing anggota.

\subsubsection{Pelibatan warga dalam kegiatan KPK Hysteria}

Pelibatan warga dalam kegiatan KPK Hysteria di Kampung Bustaman menjadi kewajiban karena KPK Hysteria menuntut warga kampung tidak hanya sebagai objek kegiatan melainkan ikut menjadi subjek dari kegiatan pelestarian Kampung Bustaman yang KPK Hysteria lakukan. Dari merancang agenda kegiatan dalam forum warga serta membantu teknis sebagai penampil dalam festival dilakukan oleh warga Kampung Bustaman. Puncaknya ada di tahap provokasi Hysteria terhadap warga Bustaman sehingga warga menghasilkan festival tahunan "Gebyuran Bustaman." Acara tersebut diselenggarakan setiap tahun satu minggu menjelang bulan Ramadhan.

3.3. Peningkatan modal sosial kampung Bustaman antara Sebelum dan Sesudah Upaya Pelestarian Kampung Bustaman oleh KPK Hysteria

Kegiatan festival Tengok Bustaman 2013, 2015, 2017 oleh KPK Hysteria terbukti mampun meningkatkan modal sosial kampung Bustaman, sama seperti teori yang dikemukakan (Ann Dale, 2005) beberapa perubahan terjadi secara positif. Dari norma sosial, control sosial, jaringan,dan trust . Dalam gambar 10 dijelaskan peningkatan modal sosial kampung bustaman didorong oleh beberapa aktor agent of change. 


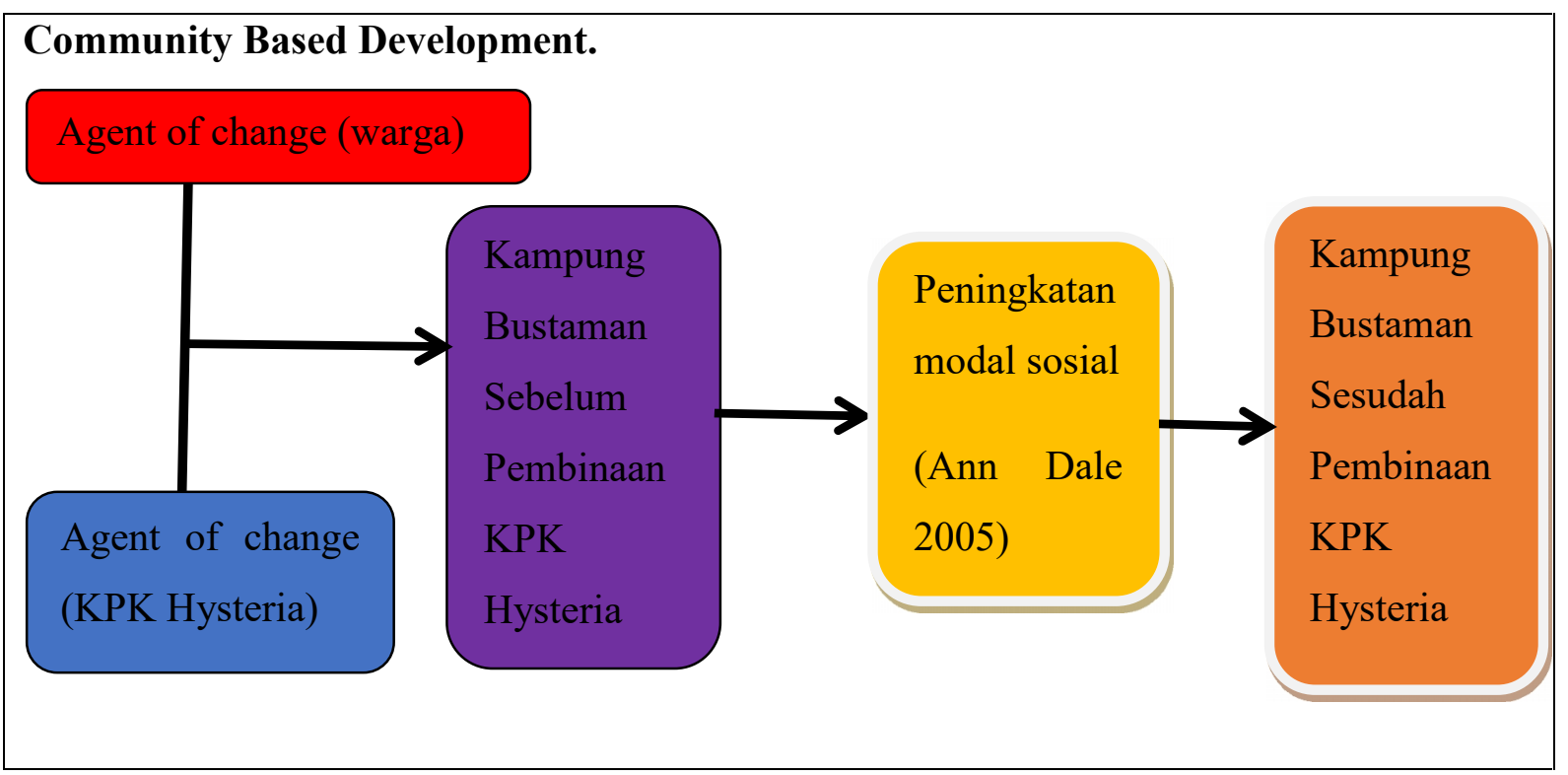

Gambar 10. Proses peningkatan Modal Sosial Kampung Bustaman Sumber : Hasil Analisis, 2018

\subsubsection{Aktor Peningkatan Modal Sosial}

Peningkatan modal sosial di kampung Bustaman ini dimotori oleh beberapa aktor baik dari KPK Hysteria maupun warga kampung bustaman sendiri. berikut aktor yang berpengaruh pada proses peningatan modal sosial kampung Bustaman:.

Tabel 3 Aktor- Aktor Penggerak Kegiatan KPK Hysteria di Kampung Bustaman

\begin{tabular}{|l|l|}
\hline NO & \multicolumn{1}{|c|}{ Aktor Pelaku } \\
\hline $\mathbf{1}$ & $\begin{array}{l}\text { Adin (33) selaku kurator dan fasilitator yang menjembatani kegiatan Tengok Bustaman. Beliau } \\
\text { sebagai pendiri KPK Hysteria yang cukup intens berinteraksi denga warga baik secara formal } \\
\text { maupun informal selama 5 tahun. }\end{array}$ \\
\hline $\mathbf{2}$ & $\begin{array}{l}\text { Openg/ Novanto K (31) anggota KPK Hysteria yang pertama kali terjun ke kampung Bustaman } \\
\text { pada September 2012. Anggota KPK Hysteriayang pertama mampu mendapatkan trust dari } \\
\text { remaja kampung Bustaman. sehingga remaja kampung Bustaman dapat diaktifasi menjadi motor } \\
\text { gerakan kegiatan KPK Hysteria di kampung Bustaman. }\end{array}$ \\
\hline $\mathbf{3}$ & $\begin{array}{l}\text { Ayah Hari Bustaman (73) Seorang tokoh masyarakat yang disegani warga kampung Bustaman , } \\
\text { dan mempunyai wawasan yang luas. Ayah hari bersama pak RW dan haji Toni mampu meredam } \\
\text { konflik warga Bustaman ketika relokasi pedagang dan prakir komunal. }\end{array}$ \\
\hline $\mathbf{4}$ & $\begin{array}{l}\text { Mas Aris Selaku Ketua RT 05 membantu translasi KPK Hysteria kepada warga Bustaman. } \\
\text { serta beliau yang menjaga pembangunan yang berkelanjutan sehari- hari di kampung Bustaman. }\end{array}$ \\
\hline $\mathbf{5}$ & $\begin{array}{l}\text { Nyong / Arya (22) tokoh remaja Bustaman yang aktif dan ikut membantu proses kegiatan KPK } \\
\text { Hysteria di kampung. Serta turut menyadarkan remaja-remaja yang lain agar ikut membantu } \\
\text { proses pelestarian kampung Bustaman }\end{array}$ \\
\hline
\end{tabular}

Sumber : Hasil Analisis, 2018

Rojab Umar Abdilla dan Linda Darmajanti 195 Strategi Komunitas Peka Kota Hysteria Dalam Pelestarian Kampung Kota ... 


\subsubsection{Peningkatan Modal Sosial di Kampung Bustaman}

\subsubsection{Norma Sosial}

Dahulu sikap warga pemalu jika ada orang luar mereka akan menyambut namun lebih minder dibandingkan sekarang sudah banyak orang datang ke Kampung Bustaman dari pelajar, mahasiswa, pejabat serta penelti-peneliti dari luar sehingga warga sudah terbiasa jika ada yang meminta wawancara akan dengan senang hati menerima. Serta warga lebih peduli akan kampung dan bangga sebagai warga Kampung Bustaman. Dibuktikan oleh program remaja untuk kerja bakti rutin per dua minggu serta menyiram tanaman setiap hari.

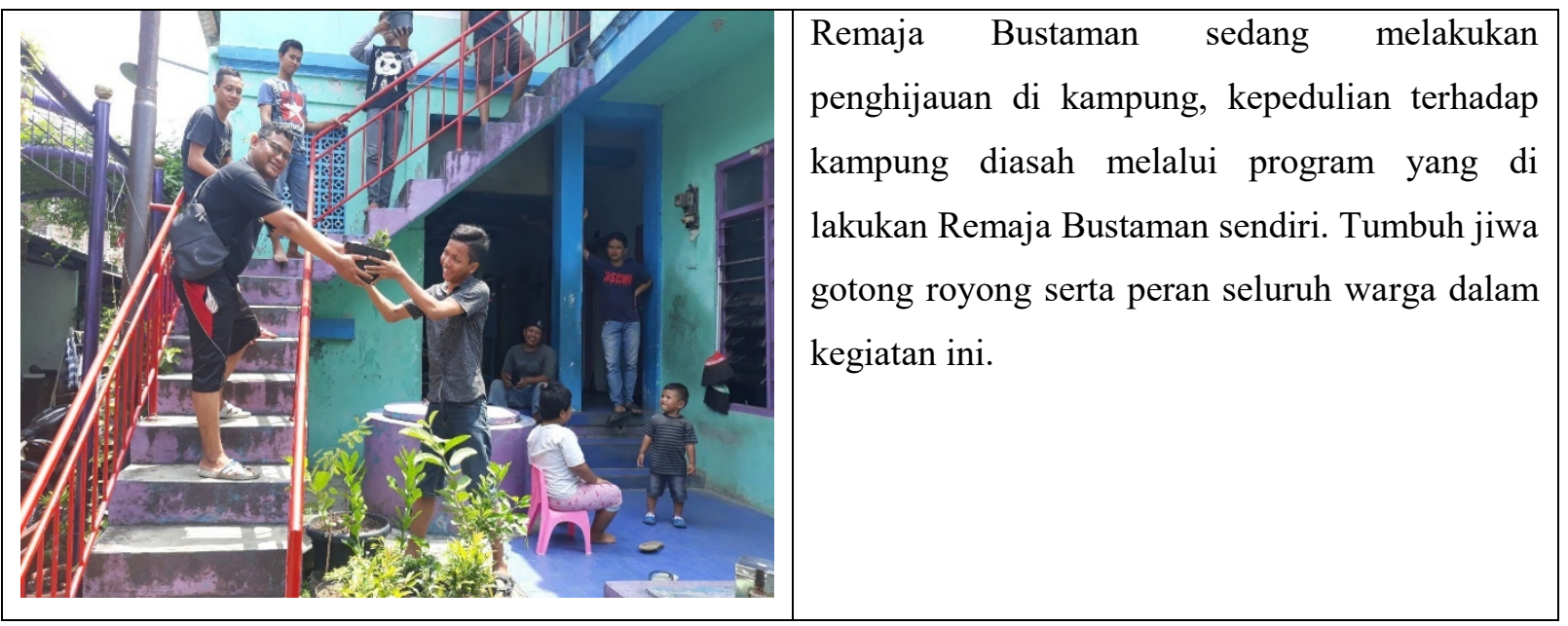

Gambar 11 Aktivitas Remaja Bustaman

Sumber : Dokumentasi, 2018

\subsubsection{Kontrol Sosial}

Dalam Tengok Bustaman ke-2 (2015) mengubah skema spasial kampung karena merelokasi pedagang yang tadinya tersebar di gang-gang dikumpukan di sebuah tempat. Lalu tempat parkir yang tadinya di depan rumah masing-masing diubah menjadi di satu tempat. Muncul sebuah kontrol sosial bagi yang masih bandel memarkirkan kendaraannya di depan rumah akan diberi sanksi dikempesi bannya langsung di tempat. 


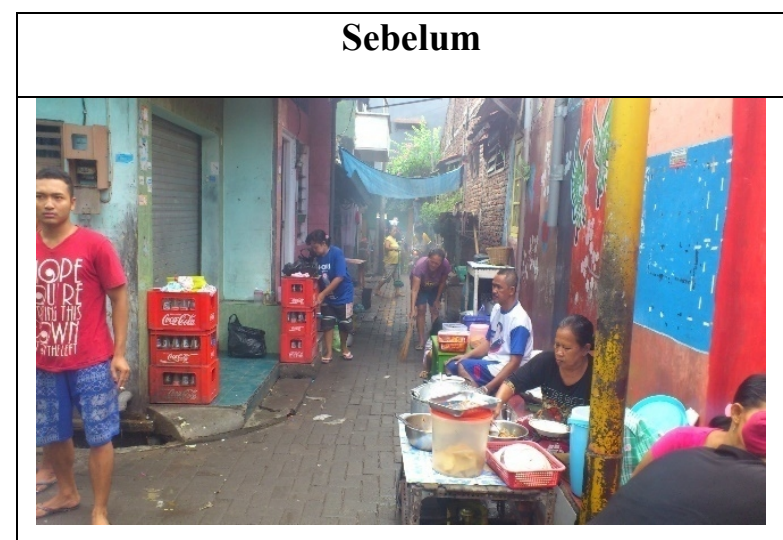

Gambar: Pedagang memenuhi gang kampung. Dok. Hysteria 2013

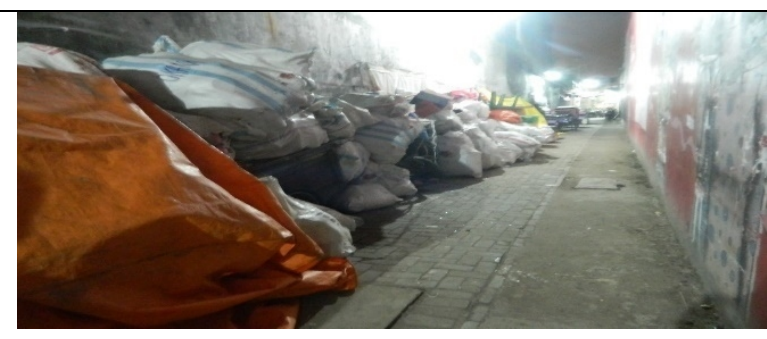

Gambar: Perkakas memenuhi gang kampung. Dok. Hysteria 2015

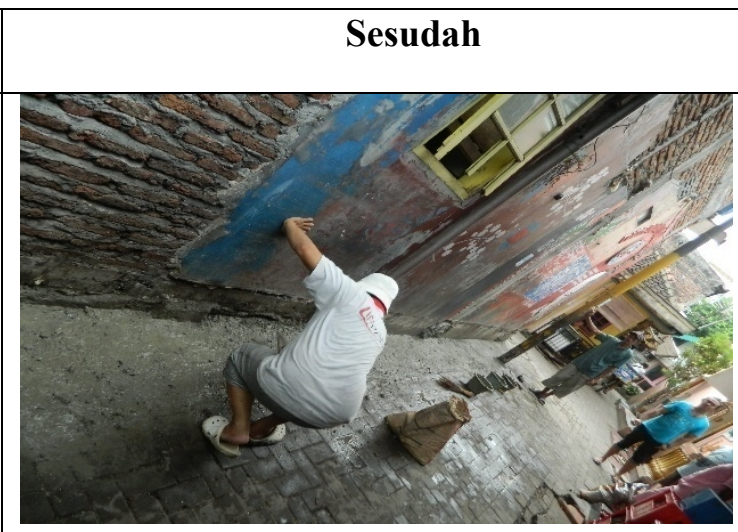

Gambar: lokasi dibersihkan dan pedagang di relokasi jadi 1 tempat. Dok. Hysteria 2015

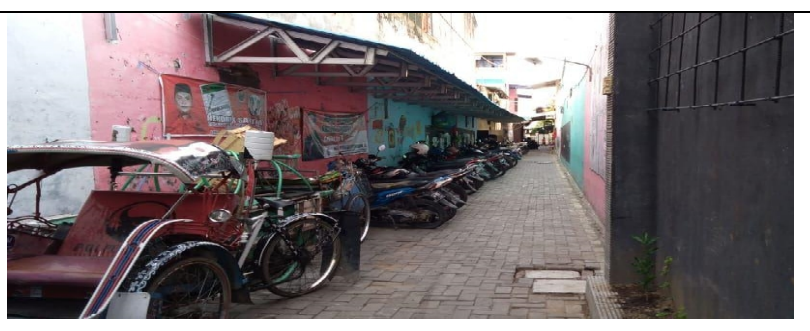

Gambar: mengubah tempat perkakas dengan parkir komunal serta dihias oleh seniman pada TB2. Dok. Hysteria 2015

\section{Gambar 12 Kontrol Sosial yang terjadi di Kampung Bustaman}

Sumber : Dokumen Hysteria, 2013-2015

\subsubsection{Trust/ Kepercayaan}

Trust / kepercayaan antarwarga semakin tumbuh terutama antar golongan, yaitu golongan orang tua kepada golongan remaja. Ketika remaja ingin menggelar acara seketika para orang tua mau untuk mendukung dengan kemampuan masing masing .

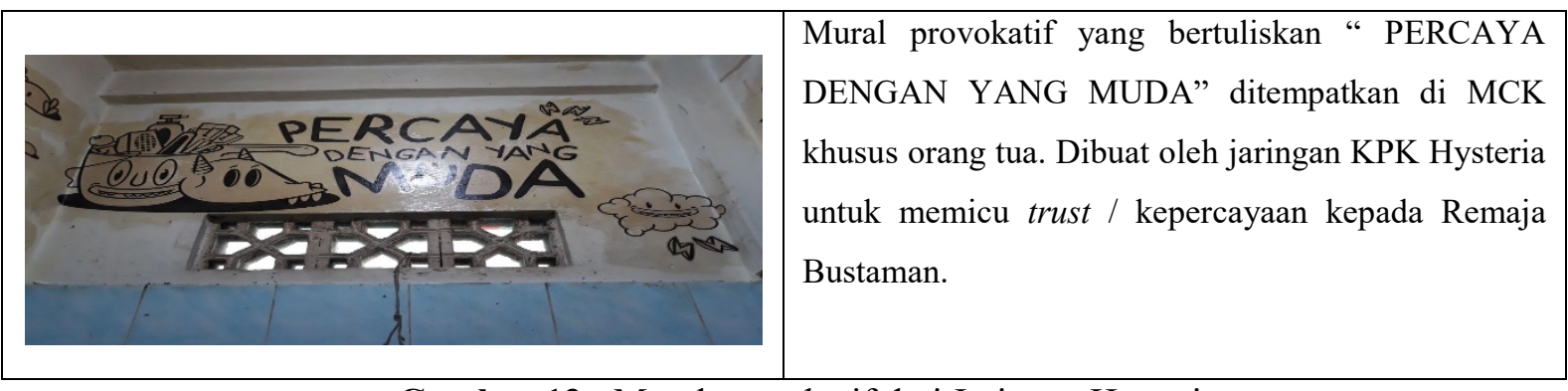

Gambar 13 : Mural provokatif dari Jaringan Hysteria

Sumber : Dokumentasi, 2018 
"Waktu dulu kami tidak dipercaya oleh bapak -bapak, tapi sekarang setiap kita ada acara , bapak- bapak atau ibu-ibu pada support terutama pada logistic /makanan, ya macemmacem bentuknya, ada yang nymbang aqua, lalu ada yang nyumbang nasi, gule, daging dan lain-lain.”(Informan B3)

\subsubsection{Jaringan/ Networking}

Jaringan dikatakan bertambah terutama bagi para remaja, ketika mengadakan acara mereka mampu mendatangkan jaringan kampung lain. Hal ini juga brmanfaat bagi remaja dengan bimbingan KPK Hysteria mampu sedikit banyak mengembangkan SDM mereka. Dengan akumulasi pertukaran informasi antar jaringan. Hal tersebut juga menjadi tujuan KPK Hysteria itu sendiri.

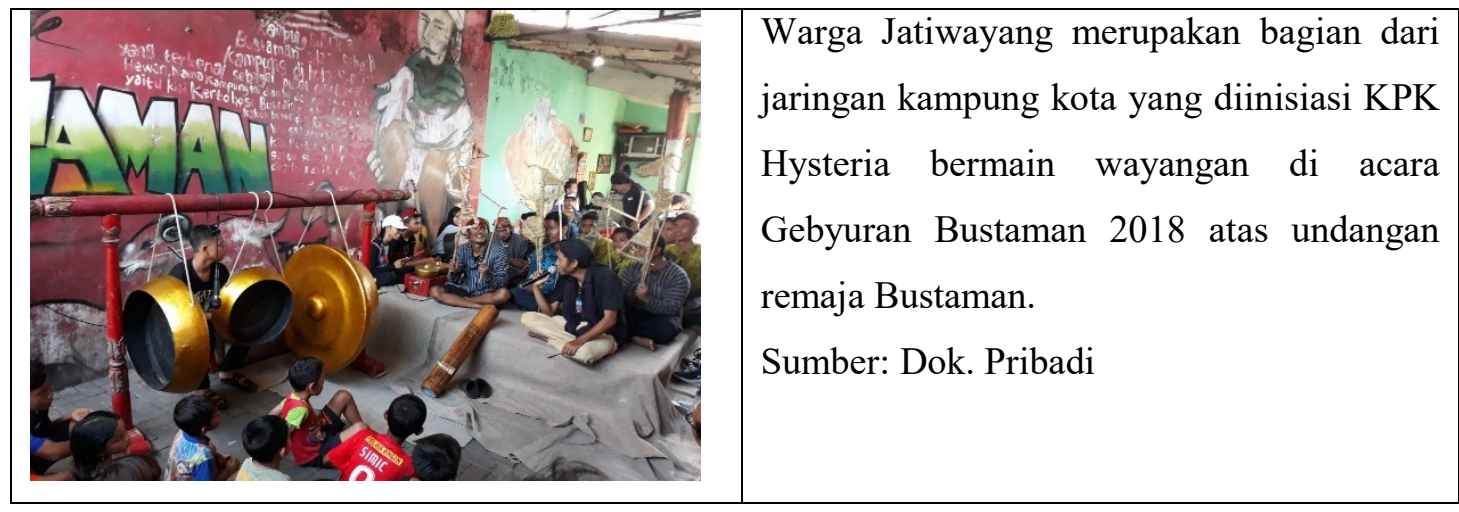

Gambar 14 Aktifitas Jejaring kampung kota

Sumber : Dokumentasi, 2018

\subsubsection{Infrastruktur}

Perubahan infrastruktur pada saat KPK Hysteria masuk ke Bustaman selama 2013 tentu banyak namun tidak terlalu signifikan. Pada 2015 mengubah skema kampung relokasi pedagang, kemudian membuat parkir komunal. Lalu pada 2017 kampung mendapat Dana Kampung Tematik dari pemerintah Kota Semarang. Dana tersebut digunakan untuk merenovasi parkiran komunal, gapura Kampung Bustaman serta mempercatnik beberapa sudut Kampung Bustaman. 


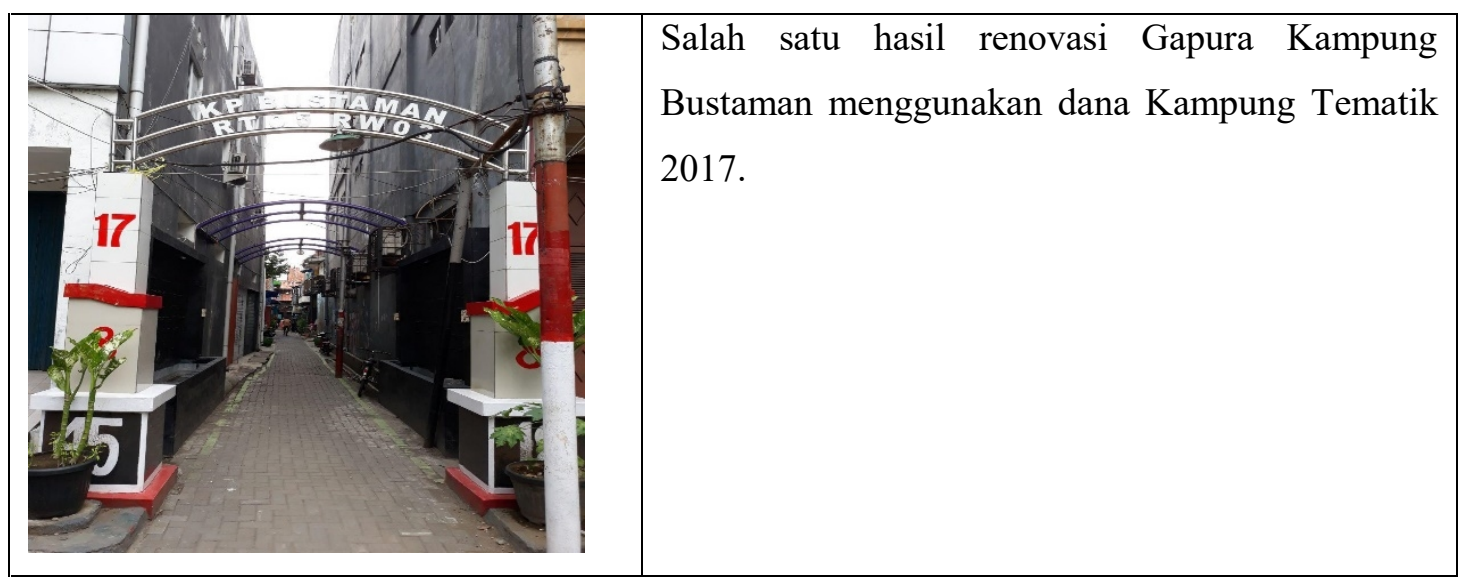

Gambar 15 Salah satu hasil renovasi penggunaan dana Kampung Tematik

Sumber : Dokumentasi, 2017

\section{KESIMPULAN DAN SARAN}

\subsection{Kesimpulan}

Komunitas Peka Kota Hysteria yang lebih dikenal dengan KPK Hysteria merupakan gerakan anak muda yang proaktif dan fokus dalam isu anak muda, seni, isu kota dan komunitas. Peneliti juga menyimpulkan bahwa ternyata dalam masyarakat perkotaaan masih ditemukan orang-orang yang peduli dalam melestarikan kampung meski bukan berasal dari kampung tersebut. Dalam upaya pelestarian kampung KPK Hysteria menggunakan tahapan tahapan atau strategi khusus untuk mencapai tujuannya. Dalam melaksanakan tahapan atau strategi tersebut dibutuhkan faktor internal serta eksternal yang memadai. Kampung Bustaman merupakan salah satu kampung lama yang Kota Semarang miliki. Kampung Bustaman masih bertahan ditengah isu penggusuran kampung yang kian marak mengingat letak geografis Kampung Bustaman berada di Kecamatan Semarang Tengah yang mana peneliti simpulkan merupakan lokasi yang strategis dan sangat diminati oleh developer.

\subsection{Saran}

KPK Hysteria hadir di Kampung Bustaman dengan strategi pendekatan berbasis budaya lokal, menggunakan media seni melalui jaringan serta melibatkan warga secara optimal dalam kegiatan pelestarian kampung Bustaman. KPK Hysteria menggunakan strategi tersebut dengan tahapan-tahapan yang sistermatis. Dalam Studi ini saya menemukan bahwa strategi KPK Hsyteria di kampung Bustaman Kota Semarang mampu meningkatkan modal sosial kampung Bustaman. Terbukti dari perubahan norma sosial, bertambahnya jaringan dan peningkatan trust antar warga. Kesuksesan ini tentu saja tidak akan terwujud apabila tidak 
didukung oleh kekuatan Internal KPK Hysteria dan Eksternal/kampung Bustaman. Suksesnya peningkatan modal sosial di kampung Bustaman diharapkan akan mewujudkan Kampung Bustaman. yang lebih Lestari.

\section{DAFTAR PUSTAKA}

Berita Penggusuran Kampung Jayenggaten .2005 https://news.detik.com/berita/388644/demopenyegelan-hotel-gumaya-semarang-nyaris-bentrok accersed 01/05/2018 10.00am

Bjornskov,C dan Svendsen,G.T.,(2000). Measuring social capital - is there a single Underlying Explanation?. Working Paper 03-05. Economics Department . Aarhus School of Business. Denmark

Budiharjo, E. (1992). Sejumlah Masalah Perkampungan Kota. Bandung: Alumnid

Coleman, J. S. (1988). Social capital in the creation of human capital. American Journal Of Sociology, 94, S95-S120.

Dale, A., \& Onyx, J. (2005). Social capital \& sustainable community development: A dynamic balance.

Darmajanti, L. (2018). Paparan Kuliah Prinsip Pengembangan Komunitas. Kajian Pengembangan Perkotaan. Universitas Indonesia. Jakarta.

Darmajanti, L. (2018). Paparan Kuliah I Pembangunan Berbasis Komuniti. Kajian Pengembangan Perkotaan, Universitas Indonesia. Jakarta

Djohan, R. (2007) Lead to Togetherness Leaders \& Social Capital (Jakarta: Fund Asia Education)

Evansyah, E., \& Dewi, S. P. (2014). Kebertahanan kampung tua Sekayu terkait keberadaan Mal Paragon di Kota Semarang. Ruang, 2(1), 1-10.

Khoirudin A. (2015). "Bok Cinta Project : Tengok Bustaman II .Semarang

Khoirudin A. (2018). "Peka Kota Hub :Sebuah perjalanan 13 Tahun Hysteria" .Semarang Koentjaraningrat. (1990). Pengantar ilmu antropologi. Jakarta: Penerbit Rineka Cipta..

Kusdi. (2009). Teori Organisasi dan Administrasi. Jakarta: Penerbit Salemba Humanika

Moleong, L. J. (2006) Qualitative Research Methodology Revised Edition (Bandung: Remaja Rosdakarya Offset) 
Rohe, W. M. (2004). Building social capital through community development. Journal of the American Planning Association, 70(2), 158-164.

Septiady, Y. (2018). Paparan Kuliah Masyarakat dan Kebudayaan Perkotaan. Kajian Pengembangan Perkotaan Universitas Indonesia, Jakarta

Soekanto, S. (2009). Sosiologi Suatu Pengantar. Jakarta: Raja Grafindo Persada

Setiawan, B (2010). 'Kampung Bagian Integral Kota.' Pidato Pengukuhan Jabatan Guru Besar Dalam Ilmu Perencanaan Kota Universitas Gadjah Mada Diucapkan di depan Rapat Terbuka Majelis Guru Besar Universitas Gadjah Mada pada tanggal 28 Oktober 2010 di Yogyakarta.

Suparlan, P. (2004). Masyarakat dan kebudayaan perkotaan: perspektif antropologi perkotaan. Jakarta : Yayasan Pengembangan Kajian Ilmu Kepolisian.

Sudarwanto, B., Hardiman, G., \& Sardjono, A. B. (2017). Pemahaman Fenomena Pengetahuan Arsitektur Kampung Kota (Kasus: Kampung Bustaman Berbasis Kuliner). NALARs, 16(2), 145-154.

Tim UGD Semarang. (2013). Tugu - Bustaman Dari Kampung Membangun Budaya Berkota. Semarang

Wijanarko (2007). Semarang Tempo Dulu: Teori Desain Kawasan Bersejarah. Yogyakarta : Ombak 